\title{
1 Nucleocapsid antigenemia is a marker of acute SARS-CoV-2 infection
}

2 Hans P. Verkerke* ${ }^{1,2}$, Gregory L. Damhorst ${ }^{* 3,4}$, Daniel S. Graciaa ${ }^{3}$, Kaleb McLendon ${ }^{1}$, William O’Sick ${ }^{1}$,

3 Chad Robichaux ${ }^{5}$, Narayanaiah Cheedarla ${ }^{1}$, Sindhu Potlapalli ${ }^{1}$, Shang-Chuen $\mathrm{Wu}^{2}$, Kristin R.V.

4 Harrington $^{5}$, Andrew Webster ${ }^{3}$, Colleen $\mathrm{Kraft}^{3}$, Christina A. Rostad ${ }^{6}$, Jesse J. Waggoner ${ }^{3,4,5,7}$, Neel R.

5 Gandhi $^{3,5}$, Jeannette Guarner ${ }^{1}$, Sara C. Auld ${ }^{5,8}$, Andrew Neish ${ }^{1}$, John D. Roback ${ }^{1}$, Wilbur A. Lam ${ }^{4,7,9,10}$, N.

6 Sarita Shah ${ }^{\dagger 3,5}$, Sean R. Stowell ${ }^{\dagger 2}$

$7 \quad *,{ }^{\dagger}$ Equal contribution

8 Affiliations:

9 1. Department of Pathology and Laboratory Medicine, Emory University School of Medicine, Atlanta, GA, USA

2. Department of Pathology, Brigham and Women's Hospital, Harvard Medical School, Boston, MA, USA

3. Division of Infectious Diseases, Department of Medicine, Emory University School of Medicine, Atlanta, GA, USA

6. Department of Epidemiology, Emory University Rollins School of Public Health, Atlanta, GA, USA

7. Department of Pediatrics and Center for Childhood Infections and Vaccines, Emory University School of Medicine and Children's Healthcare of Atlanta, Atlanta, GA, USA

8. The Atlanta Center for Microsystems-Engineered Point-of-Care Technologies, Atlanta, GA, USA Medicine, Atlanta, GA, USA 
medRxiv preprint doi: https://doi.org/10.1101/2022.01.23.22269354; this version posted January 27, 2022. The copyright holder for this preprint

(which was not certified by peer review) is the author/funder, who has granted medRxiv a license to display the preprint in perpetuity.

It is made available under a CC-BY-ND 4.0 International license .

28 Running title: Nucleocapsid antigenemia in acute SARS-CoV-2

29

30 Keywords: nucleocapsid, antigenemia, COVID-19, SARS-CoV-2

31

32 Corresponding authors:

33 Sean Stowell, MD, PhD, Brigham and Women's Hospital, Harvard Medical School,

34 srstowell@bwh.harvard.edu, (617) 291-5755

35 Sarita Shah, MD, MPH, Emory University Rollins School of Public Health, sarita.shah@emory.edu, 404

$36 \quad 727-7326$ 
medRxiv preprint doi: https://doi.org/10.1101/2022.01.23.22269354; this version posted January 27, 2022. The copyright holder for this preprint (which was not certified by peer review) is the author/funder, who has granted medRxiv a license to display the preprint in perpetuity.

It is made available under a CC-BY-ND 4.0 International license .

\section{Abstract}

Background. Reliable detection of SARS-CoV-2 infection is essential for diagnosis and treatment of disease as well as infection control and prevention during the ongoing COVID-19 pandemic. Existing nucleic acid tests do not reliably distinguish acute from resolved infection, as residual RNA is frequently

41 detected in the absence of replication-competent virus. We hypothesized that viral nucleocapsid in serum

42 or plasma may be a specific biomarker of acute infection that could enhance isolation and treatment

43 strategies at an individualized level.

44 Methods. Samples were obtained from a retrospective serological survey using a convenience sampling 45 method from adult inpatient and outpatient encounters from January through March 2021. Samples were categorized along a timeline of infection (e.g. acute, late presenting, convalescent) based on timing of

47 available SARS-CoV-2 testing and symptomatology. Nucleocapsid was quantified by digital immunoassay on the Quanterix HD-X platform.

49 Results. In a large sample of 1860 specimens from 1607 patients, the highest level and frequency of 50 antigenemia were observed in samples obtained during acute SARS-CoV-2 infection. Levels of 51 antigenemia were highest in samples from seronegative individuals and in those with more severe disease.

52 Using ROC analysis, we found that antigenemia exhibited up to $85.8 \%$ sensitivity and $98.6 \%$ specificity 53 as a biomarker for acute COVID-19.

54 Conclusions. Nucleocapsid antigenemia is a sensitive and specific biomarker for acute SARS-CoV-2 55 infection and may aid in individualized assessment of SARS-CoV-2 infection resolution or persistence, 56 although interpretation is limited by absence of a diagnostic gold standard for active infection. 
medRxiv preprint doi: https://doi.org/10.1101/2022.01.23.22269354; this version posted January 27, 2022. The copyright holder for this preprint (which was not certified by peer review) is the author/funder, who has granted medRxiv a license to display the preprint in perpetuity.

It is made available under a CC-BY-ND 4.0 International license .

\section{Introduction}

Although the standard of care for SARS-CoV-2, reverse transcription polymerase chain reaction

59 (RT-PCR) remains an imperfect diagnostic marker for coronavirus disease 2019 (COVID-19) because

60 SARS-CoV-2 RNA commonly persists beyond the period of acute infection [1-3]. Accordingly, Centers

61 for Disease Control and Prevention (CDC) guidelines do not recommend re-testing most individuals by

62 RT-PCR within 90 days following diagnosis. Instead, isolation guidelines are based on time from

63 symptom onset $[4,5]$. This creates a dilemma when screening tests detect SARS-CoV-2 RNA in a patient

64 without well-defined onset or resolution of COVID-like illness. Alternative molecular markers for acute

65 infection are not widely available [6] and low sensitivity respiratory antigen testing may be effectively

66 applied at a population level [7,8], but there remains a need for more sensitive and specific diagnostics to

67 provide individualized guidance.

The presence of viral nucleocapsid protein in peripheral blood (antigenemia) has been demonstrated in SARS-CoV-1 and SARS-CoV-2 infection [9-21]. A blood-based antigen biomarker may have inherent advantages over upper respiratory tract antigen testing, or biomarkers such as RT-PCR

71 cycle threshold $(\mathrm{Ct})$ value and sub-genomic RNA (sgRNA), because specimen quality and quantity can be

72 standardized. Reports of antigenemia test performance as a diagnostic biomarker are inconsistent, likely

73 due to varying assay composition and inconsistent reference standards as many studies compare against

74 respiratory RT-PCR as a gold standard and fail to account for the persistence of RNA beyond acute 75 infection. settings to explore the hypothesis that nucleocapsid antigenemia is a sensitive and specific marker of acute infection as defined by a clinical timeline. Specifically, each blood sample was categorized through

79 rigorous review of clinical history and respiratory SARS-CoV-2 testing in a schema that assumes a 80 typical course of COVID-19 for all subjects. We find a strong association between acute infection and 81 nucleocapsid antigenemia, which also correlates with serostatus and disease severity. Together our 
medRxiv preprint doi: https://doi.org/10.1101/2022.01.23.22269354; this version posted January 27, 2022. The copyright holder for this preprint (which was not certified by peer review) is the author/funder, who has granted medRxiv a license to display the preprint in perpetuity.

It is made available under a CC-BY-ND 4.0 International license .

82 findings suggest antigenemia may clarify disease timing and provide needed insight in many clinical

83 settings.

84

85 Methods

86

Clinical specimens

We collected a convenience sample of residual plasma, serum, and whole blood specimens from the clinical chemistry laboratory of Emory Medical Laboratories one day per week between January 11,

892021 and March 12, 2021. These specimens were originally collected for routine clinical testing from

90 inpatient (medical/surgical wards, intensive care, obstetrics) and outpatient settings (clinics, emergency

91 department, infusion centers, ambulatory surgery). Samples were transferred to a $-80 \mathrm{C}$ repository after

92 clinical testing was completed, but prior to being discarded. More than one blood sample from the same

93 patient was permitted with a minimum time of five days between samples. This study was approved and

94 granted complete HIPAA and consent waiver by the Emory University Institutional Review Board

95 (STUDY00000510).

$97 \quad$ Nucleocapsid assay

98 Nucleocapsid antigenemia was quantified on the Quanterix HD-X platform. Residual serum and

99 plasma samples were thawed once after storage at $-80^{\circ} \mathrm{C}$ and diluted 1 to 3 in assay sample diluent.

100 Diluted samples were then run using the ultrasensitive SIMOA SARS-CoV-2 N Protein Antigen assay on

101 the automated Quanterix HD-X platform (Quanterix, Billerica, MA, USA) which has a validated limit of

102 detection of $0.099 \mathrm{pg} / \mathrm{mL}$ in respiratory and saliva samples. Samples with antigen levels too high for the

103 linear range of the assay were further diluted 1 to 20 and re-tested. Final antigen concentrations were

104 determined by interpolation after sigmoidal fitting of duplicate calibration curves run on each test plate.

105

106 Serological Testing 
medRxiv preprint doi: https://doi.org/10.1101/2022.01.23.22269354; this version posted January 27, 2022. The copyright holder for this preprint (which was not certified by peer review) is the author/funder, who has granted medRxiv a license to display the preprint in perpetuity.

It is made available under a CC-BY-ND 4.0 International license .

109 of antigenemia testing. Antibody class-specific RBD serologies were performed as previously described

110 [22]. Nucleocapsid antibody testing was performed using an in-house developed ELISA (supplementary

111 information).

\section{Medical record review}

114 Patient medical record number was recorded at the time of specimen collection. The Emory

115 Healthcare Clinical Data Warehouse (CDW) was queried for SARS-CoV-2 nucleic acid amplification 116 tests (NAAT), clinical notes, ICD-10 codes, laboratory values, mechanical ventilation, and date of death.

117 All Ct values were obtained directly from reports produced by the manufacturer's software 118 (supplementary information).

A COVID-19 status label (positive or negative) and a category (convalescent, late-presenting, acute, pre-COVID, and same-day negative) were assigned to each blood sample based on that patient's

121 (1) SARS-CoV-2 respiratory testing (including NAAT or antigen), (2) date of earliest positive test, and

122 (3) date of symptom onset (Figure 1).

Chart review began with automated review of NAAT results available in the medical record.

124 Blood samples from a patient with a positive NAAT more than fourteen days prior to sample collection

125 were labeled convalescent and no further review of the medical record for categorization purposes was 126 performed. History and physical clinical notes dated within fourteen days before or after the date of the 127 blood sample were then reviewed, if available, for all patients not labeled convalescent. Date of COVID128 like symptom onset (including fever, fatigue, malaise, myalgia, headache, dyspnea, cough, wheezing, 129 anosmia, ageusia, congestion, rhinorrhea, or diarrhea) and earliest positive SARS-CoV-2 testing (NAAT 130 or antigen) was recorded if these had been described in the history narrative or clinician's assessment and 131 plan. 
medRxiv preprint doi: https://doi.org/10.1101/2022.01.23.22269354; this version posted January 27, 2022. The copyright holder for this preprint (which was not certified by peer review) is the author/funder, who has granted medRxiv a license to display the preprint in perpetuity.

It is made available under a CC-BY-ND 4.0 International license .

The original medical records were then reviewed for all patients (other than those labeled convalescent) with a positive SARS-CoV-2 test who did not yet have date of symptom onset recorded in

134 our data set. The entire medical record was available during this stage, but the reviewer was blinded to 135 antigenemia status which was not considered in labeling of COVID-19 status or category assignment.

136 Given that re-infection with SARS-CoV-2 was rare at the time of this study [23], our approach 137 assumed that no re-infection events were captured in our sample set, which spanned 3 months. Patients 138 without any record of SARS-CoV-2 testing were excluded from analysis. Further detail is provided in 139 Supplementary Information.

\section{Data analysis}

Data obtained during specimen collection were stored in Microsoft Excel. CDW reports were provided in .csv format. All data were then imported into MATLAB (The MathWorks, Inc.) for analysis.

144 Wilcoxon rank-sum test was used for comparisons.

\section{Results} exhibited detectable nucleocapsid. 115 of 2,487 were excluded due to lack of patient identifiers and five

152 additional samples were excluded as they had been collected on the same day as another blood sample 153 from a single patient. Clinical data were examined for the remaining 2,367 samples from 2,101 unique 154 patients (Table 1). 507 of 2,367 samples were excluded because of no record of SARS-CoV-2 testing, 155 and 11 of these 507 (2.1\%) had detectable antigenemia.

156 The remaining 1,860 samples from 1,607 patients had SARS-CoV-2 testing records to guide 157 categorization and were classified as described in Figure 1B and Table 2. 
medRxiv preprint doi: https://doi.org/10.1101/2022.01.23.22269354; this version posted January 27, 2022. The copyright holder for this preprint (which was not certified by peer review) is the author/funder, who has granted medRxiv a license to display the preprint in perpetuity.

It is made available under a CC-BY-ND 4.0 International license .

Diagnostic performance of antigenemia for acute COVID-19

Nucleocapsid antigenemia was present at higher frequency and with a higher median

161 concentration in acute COVID samples compared to samples categorized as late-presenting, convalescent,

162 pre-COVID, or same-day negative ( $\mathrm{p}<0.001$ for all comparisons; Figure 2A). ROC analysis

163 demonstrated area under the curve (AUC) of 0.902 in distinguishing samples from patients experiencing

164 acute infection from all non-acute categories, and sensitivity and specificity were $85.2 \%$ and $89.9 \%$,

165 respectively (Figure 2B). Test characteristics with censoring of the potentially ambiguous late-presenting

166 group showed AUC 0.914 , sensitivity $85.8 \%$, and specificity $93.7 \%$ while the most stringent comparison

167 (censoring of the convalescent and late-presenting groups) demonstrated AUC 0.972, sensitivity 85.8\%,

168 and specificity $98.6 \%$. Sensitivity improved to $93.9 \%$ when the comparison was only made among

169 seronegative individuals (Supplementary Figure 1).

Test characteristics were also examined when adjusting the reference standard by varying

171 parameters of the acuity window. Sensitivity decreased as the window start period increased beyond -11

172 days (Figure 2C). Meanwhile, specificity consistently increased as the period of the acuity window was

173 lengthened. Maximum AUC was observed with a window period opening at -12 days (AUC $=0.912$ with

174 window close at +3 days) with minimal effect of varying the post-sampling period from 0 to +3 days

175 (Figure 2D).

176 Ct values from positive nasopharyngeal RT-PCR were available from the same day as a blood

177 sample for 49 specimens. Only 6 of 17 samples with corresponding to $\mathrm{Ct}$ values greater than 33 had

178 antigenemia and four of six of these were from the GeneXpert assay (Figure 2E). All except for two

179 samples with corresponding $\mathrm{Ct}$ values less than 30 exhibited antigenemia.

Temporal trends in antigenemia

182 We analyzed the dynamics of antigen level over time in samples from the acute, late-presenting

183 and convalescent groups. The frequency of detectable nucleocapsid and antigen concentration decreased 
medRxiv preprint doi: https://doi.org/10.1101/2022.01.23.22269354; this version posted January 27, 2022. The copyright holder for this preprint (which was not certified by peer review) is the author/funder, who has granted medRxiv a license to display the preprint in perpetuity.

It is made available under a CC-BY-ND 4.0 International license .

184

185

186

187

188

189

190

191

192

193

194

195

196

197

198

199

200

201

202

203

204

205

206

207

208

over time following diagnosis and reported symptom onset (Figures 3A-B). 18 samples were identified from patients who were asymptomatic at the time of COVID-19 diagnosis, 5 (27.7\%) of which had detectable nucleocapsid antigenemia. Nucleocapsid antigen was detected more frequently $(50.0 \%)$ in the subset of samples available from asymptomatic patients within 3 days of their diagnosis (Figure 3C). Among 55 samples from individuals with positive respiratory RT-PCR testing on the same day, seven convalescent samples did not exhibit antigenemia (Figure 3D, Supplementary Table 1) and acute infections primarily exhibited high antigenemia. Among this subset of patients, no antigenemia was observed more than fourteen days after the earliest known positive test (Figure 3D).

\section{Examination of outliers}

We reviewed medical records for individuals with unexpected presence or absence of antigenemia. Twenty-one samples in the convalescent group had antigenemia (Supplementary Table 2, Supplementary Figure 2). Among these, two individuals had clinical history consistent with re-infection by SARS-CoV-2, two were highly immunocompromised, and eleven samples (median time from diagnosis 20 days, IQR 16.5-28.5 days) had severe COVID-19 marked by need for high-flow oxygen, intubation or death. End-stage renal disease or dialysis was more common among samples in the convalescent group with antigenemia compared to those without antigenemia (fraction [95\% confidence interval $]=0.41[0.20-0.61]$ vs $0.13[0.07-0.18])$ whereas other co-morbidities were not significantly different (Supplementary Figure 3). Three individuals had negative respiratory SARS-CoV-2 testing and antigenemia on the same day, none of which had evidence of COVID-related symptoms (Supplementary Table 3). Eighteen samples had antigenemia after more than fourteen days of symptoms, of which fourteen were seropositive for both $\mathrm{N} \mathrm{IgG}$ and RBG IgG, two seropositive for RBD IgG only, and two were seronegative for both. Thirteen had nucleocapsid level less than $46 \mathrm{pg} / \mathrm{mL}$ while the other five exceeded $700 \mathrm{pg} / \mathrm{mL}$ including both $\mathrm{N}$ and RBD seronegative patients and N-/RBD+ sample (Supplementary Table 4, Supplementary Figures 4 \& 5). Twenty individuals with samples 
medRxiv preprint doi: https://doi.org/10.1101/2022.01.23.22269354; this version posted January 27, 2022. The copyright holder for this preprint (which was not certified by peer review) is the author/funder, who has granted medRxiv a license to display the preprint in perpetuity.

It is made available under a CC-BY-ND 4.0 International license .

categorized in the acute COVID group did not have antigenemia - ten of these were collected ten or more days after symptom onset (Supplementary Table 5, Supplementary Figure 6). higher median values in seronegative samples compared to seropositive samples for nucleocapsid $\operatorname{IgG}$, were also more likely to have undetectable antigenemia. Similar trends were seen in the late-presenting group except for the comparison based on IgM which was not significant (Supplementary Figure 7).

In the acute COVID group, distribution of nucleocapsid antigen was significantly different and associated with elevated CRP ( $p=0.002$ in comparison based on $40 \mathrm{mg} / \mathrm{L}$ cutoff; Figure 5D-E).

\section{Discussion}

This analysis of blood samples from routine clinical specimens collected during the ongoing COVID-19 pandemic demonstrates the following: First, antigenemia is a sensitive and specific marker for acute SARS-CoV-2 infection. Second, nucleocapsid is elevated in samples without evidence of antinucleocapsid (IgG) and anti-spike (IgG, $\operatorname{IgM}$, and $\operatorname{IgA}$ ) seroconversion. Third, antigenemia is associated 232 with disease severity.

Evolving CDC isolation guidance during the COVID-19 pandemic reflects the difficulty of 234 objectively defining resolution of SARS-CoV-2 infection. Underlying this is the persistence of RNA 
medRxiv preprint doi: https://doi.org/10.1101/2022.01.23.22269354; this version posted January 27, 2022. The copyright holder for this preprint (which was not certified by peer review) is the author/funder, who has granted medRxiv a license to display the preprint in perpetuity.

It is made available under a CC-BY-ND 4.0 International license.

235

236

237

238

239

240

241

242

targets beyond a period during which the immunocompetent individual is reasonably believed to harbor replication-competent virus [1-3]. Meanwhile, persistence of replication-competent virus for months has been demonstrated by viral culture in immunocompromised hosts [24-28]. This creates a diagnostic dilemma when RT-PCR is persistently positive for weeks after diagnosis, when re-infection with SARSCoV-2 is a consideration, or when encountering positive SARS-CoV-2 RT-PCR test results in an asymptomatic individual without history of prior objective diagnosis or prior COVID-like illness. Our data suggest assessment of nucleocapsid antigenemia may assist providers in making judgments in these scenarios.

Further, our data compels interest in whether antigenemia may provide direct evidence of active viral replication, which aid in evaluation of infectiousness or guide therapeutics at an individualized level. For example, antiviral agents are not likely to benefit a patient without active SARS-CoV-2 replication. Clinical trial data therefore may be confounded by failure to stratify patients according to such a marker, as late presenters after cessation of viral replication would likely fail to show benefit or may even suffer harm from investigatory antiviral agents. In fact, recent evidence emphasizes benefit of antivirals early in infection [29]. In showing its association with acute SARS-CoV-2 infection and characterizing outliers, our data suggest that nucleocapsid should be further investigated as a marker of viral activity, infectiousness, and a predictor of therapeutic response.

Strengths of our study include a diverse cohort that is among the largest in which nucleocapsid antigenemia has been quantified to date and rigorous assignment of COVID-19 status through medical record review. Prior studies restricting the definition of a positive case to no more than two weeks after symptom onset report sensitivities between $90.9 \%$ and $97.5 \%$ and specificities between $94.2 \%$ and $100 \%$ [15-20] (see Supplementary Table 6), and our data are consistent with these findings. Of further interest, our data revealed detectable antigen in $11(2.1 \%)$ of the blood samples obtained in the primary serosurvey even though these patients were never screened with nasopharyngeal RT-PCR testing in our healthcare system. These represent likely infectious patients who may have had a missed SARS-CoV-2 diagnosis 
medRxiv preprint doi: https://doi.org/10.1101/2022.01.23.22269354; this version posted January 27, 2022. The copyright holder for this preprint (which was not certified by peer review) is the author/funder, who has granted medRxiv a license to display the preprint in perpetuity.

It is made available under a CC-BY-ND 4.0 International license .

and suggest a potential role for antigenemia screening in a population for whom blood is already being sampled to complement existing infection control measures.

We also detected antigenemia in a small number of patients with subclinical SARS-CoV-2 infection. Individuals who test positive for SARS-CoV-2 without antecedent or subsequent COVID-like symptoms either represent shedding of replication-competent virus during subclinical disease or persistent RNA shedding following subclinical disease. While we corroborate previous findings that levels of antigenemia are associated with disease severity $[19,20]$, the presence of antigenemia in five asymptomatic individuals with SARS-CoV-2 demonstrates that antigenemia can also be present in subclinical infection. Despite the difficulty associated with identifying these cases, further investigation of the prevalence of antigenemia in acute asymptomatic infection is needed to clarify its role in screening broad populations.

This study is limited by use of a convenience sampling approach and retrospective data collection. Symptom onset as recorded in the medical record can be subjective and influenced by recall bias. Because of the ubiquity of community-based testing, SARS-CoV-2 diagnosis was documented prior to evaluation in our healthcare system for a subset of these patients and was only known to us when documented in the clinical narrative in addition to being subject to biases and imprecision. In addition, nucleocapsid-specific immunoglobulin may interfere with quantitation of antigenemia in individuals who have seroconverted although it is currently unknown whether total (Ig-bound and unbound) antigen or free (unbound only) antigen is a more meaningful clinical indicator. The primary analysis relies on the assumption that each subject is immunocompetent, that immunocompetent hosts have similar duration of acute COVID-19, and that there are no other confounding factors which may result in prolonged antigenemia. Recognizing these limitations, we performed a post-hoc investigation of outlier cases, which facilitated hypothesis generation regarding reasons for prolonged antigenemia such as reduced renal function, prolonged critical illness, and immune compromise (Supplementary Tables 1-5 \& 7). Several studies have demonstrated high specificity of antigenemia by evaluation of pre-pandemic samples $[15,17$, 20], suggesting many false positives in our study are likely to have active infection beyond the parameters 
medRxiv preprint doi: https://doi.org/10.1101/2022.01.23.22269354; this version posted January 27, 2022. The copyright holder for this preprint

(which was not certified by peer review) is the author/funder, who has granted medRxiv a license to display the preprint in perpetuity.

It is made available under a CC-BY-ND 4.0 International license.

286 for acute infection defined in our reference standard schema. This will be further clarified as more robust

287 comparisons to viral culture, sgRNA, RT-PCR Ct value, and respiratory antigen testing can be achieved.

288 Together our data demonstrate that nucleocapsid antigenemia is a sensitive and specific

289 biomarker of acute COVID-19 wherein COVID-19 status is defined by time since earliest positive testing

290 and symptom onset. We conclude that nucleocapsid antigenemia is a promising candidate biomarker for

291 active viral replication - the definition of which is the presence of replication-competent virus in a host -

292 recognizing that the available evidence points to this being an individualized process that cannot be

293 broadly defined based on a timeline. Further prospective studies with rigorous documentation of clinical

294 course and correlation with viral culture and other potential biomarkers of viral replication are needed. 
medRxiv preprint doi: https://doi.org/10.1101/2022.01.23.22269354; this version posted January 27, 2022. The copyright holder for this preprint (which was not certified by peer review) is the author/funder, who has granted medRxiv a license to display the preprint in perpetuity.

It is made available under a CC-BY-ND 4.0 International license .

\section{Acknowledgments}

296 The authors thank Lisa Cole, Cecillitha J Williams, and Mark Meyers for assistance with specimen

297 collection and Heather Jones for assistance with obtaining Ct values.

299 Funding

300 This work was supported by funds from the Woodruff Health Sciences Center COVID-19 Center for

301 Urgent Research Engagement (CURE), NIH 1 U54 CA260563-01: Immune regulation of COVID-19

302 infection in cancer and autoimmunity to JDR, NIH R01 HL138656 COVID-19 supplement to SRS, NIH

303 R01 AI138646 supplement to NSS, NIH K24 AI114444 to NRG, and NIH Grants U54 EB027690 03 and

$304 \quad$ UL1TR002378.

305

306 Conflicts of Interest

307 C.A.R.'s institution has received funds to conduct clinical research unrelated to this manuscript from

308 BioFire Inc, GSK, MedImmune, Micron, Janssen, Merck, Moderna, Novavax, PaxVax, Pfizer,

309 Regeneron, Sanofi-Pasteur. She is co-inventor of patented RSV vaccine technology unrelated to this

310 manuscript, which has been licensed to Meissa Vaccines, Inc.

311 All other authors report no conflicts of interest.

312

\section{Human Subjects Research}

314 This study was approved by the Institutional Review Board of Emory University for the use of residual

315 clinical specimens. Written informed consent by the patients was not required. 
medRxiv preprint doi: https://doi.org/10.1101/2022.01.23.22269354; this version posted January 27, 2022. The copyright holder for this preprint (which was not certified by peer review) is the author/funder, who has granted medRxiv a license to display the preprint in perpetuity.

It is made available under a CC-BY-ND 4.0 International license .

\section{References}

1. Cevik M, Tate M, Lloyd O, Maraolo AE, Schafers J, Ho A. SARS-CoV-2, SARS-CoV, and MERS-CoV viral load dynamics, duration of viral shedding, and infectiousness: a systematic review and meta-analysis. The Lancet Microbe 2021; 2(1): e13-e22.

2. Yan D, Zhang X, Chen C, et al. Characteristics of Viral Shedding Time in SARS-CoV-2 Infections: A Systematic Review and Meta-Analysis. Front Public Health 2021; 9: 652842.

3. Drain PK. Rapid Diagnostic Testing for SARS-CoV-2. New England Journal of Medicine 2022.

4. Prevention CfDCa. COVID-19 Quarantine and Isolation. Available at: https://www.cdc.gov/coronavirus/2019-ncov/your-health/quarantine-isolation.html. Accessed $11 / 29 / 2021$.

5. Prevention CfDCa. CDC Updates and Shortens Recommended Isolation and Quarantine Period for General Population. CDC Newsroom Releases 2021; 2021(December 29, 2021).

6. Binnicker MJ. Can Testing Predict SARS-CoV-2 Infectivity? The Potential for Certain Methods to be a Surrogate for Replication-Competent Virus. J Clin Microbiol 2021: JCM0046921.

7. Mina MJ, Parker R, Larremore DB. Rethinking Covid-19 Test Sensitivity - A Strategy for Containment. New England Journal of Medicine 2020; 383(22): e120.

8. Chin ET, Huynh BQ, Chapman LAC, Murrill M, Basu S, Lo NC. Frequency of Routine Testing for Coronavirus Disease 2019 (COVID-19) in High-risk Healthcare Environments to Reduce Outbreaks. Clinical Infectious Diseases 2020.

9. Che X-Y, Hao W, Wang Y, et al. Nucleocapsid Protein as Early Diagnostic Marker for SARS. Emerging Infectious Diseases 2004; 10(11): 1947-9.

10. Li Y-H, Li J, Liu X-E, et al. Detection of the nucleocapsid protein of severe acute respiratory syndrome coronavirus in serum: Comparison with results of other viral markers. Journal of Virological Methods 2005; 130(1-2): 45-50.

11. Li T, Wang L, Wang H, et al. Serum SARS-COV-2 Nucleocapsid Protein: A Sensitivity and Specificity Early Diagnostic Marker for SARS-COV-2 Infection. Front Cell Infect Microbiol 2020; 10 : 470.

12. Lebedin YS, Lyang OV, Galstyan AG, Panteleeva AV, Belousov VV, Rebrikov DV. Serum SARS-CoV-2 nucleocapsid antigen detection is essential for primary diagnostics of SARS-CoV2-associated pneumonia. medRxiv: Cold Spring Harbor Laboratory, 2020.

13. Su B, Yin J, Lin X, et al. Quantification of SARS-CoV-2 antigen levels in the blood of patients with COVID-19. Sci China Life Sci 2021; 64(7): 1193-6.

14. Ogata AF, Maley AM, Wu C, et al. Ultra-sensitive Serial Profiling of SARS-CoV-2 Antigens and Antibodies in Plasma to Understand Disease Progression in COVID-19 Patients with Severe Disease. Clin Chem 2020.

15. Hingrat QL, Visseaux B, Laouenan C, et al. Detection of SARS-CoV-2 N-antigen in blood during acute COVID-19 provides a sensitive new marker and new testing alternatives. Clin Microbiol Infect 2020.

16. Ahava M, Kurkela S, Kuivanen S, Lappalainen M, Jarva H, Jääskeläinen A. Detection of SARSCoV-2 nucleocapsid antigen from serum can aid in timing of COVID-19 infection. medRxiv. medRxiv: Cold Spring Harbor Laboratory, 2021.

17. Shan D, Johnson JM, Fernandes SC, et al. N-protein presents early in blood, dried blood and saliva during asymptomatic and symptomatic SARS-CoV-2 infection. Nat Commun 2021; 12(1): 1931.

18. Zhang Y, Ong CM, Yun C, et al. Diagnostic Value of Nucleocapsid Protein in Blood for SARSCoV-2 Infection. Clinical Chemistry 2021.

19. Wang $\mathrm{H}$, Hogan CA, Verghese $\mathrm{M}$, et al. SARS-CoV-2 Nucleocapsid Plasma Antigen for Diagnosis and Monitoring of COVID-19. Clin Chem 2021.

20. Favresse J, Bayart J-L, David C, et al. Serum SARS-CoV-2 Antigens for the Determination of COVID-19 Severity. medRxiv: Cold Spring Harbor Laboratory, 2021. 
medRxiv preprint doi: https://doi.org/10.1101/2022.01.23.22269354; this version posted January 27, 2022. The copyright holder for this preprint (which was not certified by peer review) is the author/funder, who has granted medRxiv a license to display the preprint in perpetuity.

It is made available under a CC-BY-ND 4.0 International license.

366

367

368

369

370

371

372

373

374

375

376

377

378

379

380

381

382

383

384

385
21. Thudium RF, Stoico MP, Hogdall E, et al. Early Laboratory Diagnosis of COVID-19 by Antigen Detection in Blood Samples of the SARS-CoV-2 Nucleocapsid Protein. J Clin Microbiol 2021; 59(10): e0100121.

22. Verkerke H, Horwath M, Saeedi B, et al. Comparison of Antibody Class-Specific SARS-CoV-2 Serologies for the Diagnosis of Acute COVID-19. J Clin Microbiol 2021; 59(4).

23. !!! INVALID CITATION !!! [22].

24. Choi B, Choudhary MC, Regan J, et al. Persistence and Evolution of SARS-CoV-2 in an Immunocompromised Host. N Engl J Med 2020; 383(23): 2291-3.

25. Avanzato VA, Matson MJ, Seifert SN, et al. Case Study: Prolonged Infectious SARS-CoV-2 Shedding from an Asymptomatic Immunocompromised Individual with Cancer. Cell 2020; 183(7): 1901-12 e9.

26. Hensley MK, Bain WG, Jacobs J, et al. Intractable COVID-19 and Prolonged SARS-CoV-2 Replication in a CAR-T-cell Therapy Recipient: A Case Study. Clin Infect Dis 2021.

27. Aydillo T, Gonzalez-Reiche AS, Aslam S, et al. Shedding of Viable SARS-CoV-2 after Immunosuppressive Therapy for Cancer. N Engl J Med 2020; 383(26): 2586-8.

28. McCarthy KR, Rennick LJ, Nambulli S, et al. Recurrent deletions in the SARS-CoV-2 spike glycoprotein drive antibody escape. Science 2021; 371(6534): 1139-42.

29. Gottlieb RL, Vaca CE, Paredes R, et al. Early Remdesivir to Prevent Progression to Severe Covid-19 in Outpatients. New England Journal of Medicine 2021. 
medRxiv preprint doi: https://doi.org/10.1101/2022.01.23.22269354; this version posted January 27, 2022. The copyright holder for this preprint (which was not certified by peer review) is the author/funder, who has granted medRxiv a license to display the preprint in perpetuity.

It is made available under a CC-BY-ND 4.0 International license .

\begin{tabular}{|c|c|c|c|}
\hline & Positive & Negative & Undefined \\
\hline $\mathbf{N}$ & 130 & 385 & 1622 \\
\hline Age mean (IQR) & $60.6(52.2-73.0)$ & $54.2(39.2-69.6)$ & $55.0(39.8-70.2)$ \\
\hline Female \% & 47.7 & 57.1 & 55.5 \\
\hline Vaccinated \% & 1.5 & 4.7 & 9.9 \\
\hline \multicolumn{4}{|l|}{ Race $\%$} \\
\hline African American or Black & 78.5 & 72.0 & 60.7 \\
\hline American Indian or Alaskan Native & 0.0 & 0.0 & 0.2 \\
\hline Asian & 0.8 & 1.0 & 1.6 \\
\hline Caucasian or White & 13.1 & 20.0 & 29.0 \\
\hline Native Hawaiian or Other Pacific Islander & 0.0 & 0.3 & 0.2 \\
\hline Multiple & 0.0 & 0.5 & 0.4 \\
\hline Unknown, Unavailable or Unreported & 7.7 & 6.2 & 7.9 \\
\hline \multicolumn{4}{|l|}{ Ethnicity } \\
\hline Non-Hispanic or Latino & 83.9 & 86.0 & 84.4 \\
\hline Unreported, Unknown, Unavailable & 13.9 & 7.8 & 11.9 \\
\hline Hispanic or Latino & 0.8 & 5.5 & 3.0 \\
\hline Not Recorded & 1.5 & 0.8 & 0.7 \\
\hline Antigenemia* \% & 85.8 & 10.1 & 3.9 \\
\hline \multicolumn{4}{|l|}{ Setting* } \\
\hline Inpatient & 70.9 & 42.9 & 39.3 \\
\hline $\mathrm{ER}$ or $\mathrm{CDU}$ & 29.1 & 27.2 & 14.1 \\
\hline Outpatient & 0.0 & 26.7 & 45.3 \\
\hline Peripartum & 0.0 & 3.3 & 1.1 \\
\hline
\end{tabular}

Table 1. Summary of patient characteristics by COVID status.

*Reflects all included samples (including multiple samples for a unique patient). CDU = clinical decision unit 
medRxiv preprint doi: https://doi.org/10.1101/2022.01.23.22269354; this version posted January 27, 2022. The copyright holder for this preprint (which was not certified by peer review) is the author/funder, who has granted medRxiv a license to display the preprint in perpetuity.

It is made available under a CC-BY-ND 4.0 International license .

\section{Samples Unique patients}

\begin{tabular}{|c|c|c|}
\hline Never SARS-CoV-2 positive & 1416 & 1249 \\
\hline Same-day negative NAAT & 194 & 194 \\
\hline Ever SARS-CoV-2 positive* & 444 & 360 \\
\hline Convalescent & 182 & 153 \\
\hline Late-presenting & 30 & 30 \\
\hline Acute & 141 & 130 \\
\hline Sampled three or more days prior to diagnosis & 42 & 34 \\
\hline Negative interim testing & 21 & 16 \\
\hline
\end{tabular}

Table 2. Categories determined by chart review for samples and patients included in the analysis.

NAAT $=$ Nucleic acid amplification testing; $*$ Includes in-hospital NAAT as well as community NAAT or antigen testing if reported in the clinical narrative 
medRxiv preprint doi: https://doi.org/10.1101/2022.01.23.22269354; this version posted January 27, 2022. The copyright holder for this preprint (which was not certified by peer review) is the author/funder, who has granted medRxiv a license to display the preprint in perpetuity.

It is made available under a CC-BY-ND 4.0 International license.

\section{Figure captions}

Figure 1. (A) Schematic of process for COVID status assignment. Samples from patients with no record of positive SARS-CoV-2 respiratory testing were only considered negative if corresponding negative respiratory testing occurred on the same day. Due to the lack of a gold standard for active SARS-CoV-2 infection, samples from individuals with history of positive SARS-CoV-2 testing are labeled based on earliest known positive SARS-CoV-2 respiratory test and time since symptom onset. (B) Flow chart of categorization and labeling process indicating number of samples assigned to each group.

Figure 2. (A) Prevalence of antigenemia and serum or plasma nucleocapsid levels for blood samples by category. Unexpected results (presence of nucleocapsid in the convalescent and same-day negative groups, absence of nucleocapsid in the acute group) are examined in Supplementary Information Tables 2-5. (B) ROC curve for diagnostic performance of detectable antigenemia with reference to a $-14 /+3$ day window for acute infection. The additional curves progressively exclude ambiguous categories. (C) Impact on sensitivity and specificity of varying the window period, which defines the reference standard for acute COVID. (D) AUC for the same varied window periods. (E) Antigenemia compared to RTPCR Ct value for those specimens with a $\mathrm{Ct}$ value available from the clinical laboratory on the same day. Symbols correspond to assay and gene target with horizontal line linking $\mathrm{Ct}$ values for different targets detected in the same sample. This includes data from four assays on three thermocycler platforms described in further detail in Supplementary Information.

Figure 3. (A) Serum or plasma nucleocapsid plotted against time since diagnosis (top) and symptom onset (bottom, shown with an inverted y axis). Samples without antigen detected are shown stacked on the common horizontal axis. Four samples with antigenemia beyond 41 days are listed in the box and 93 samples without antigenemia between 41 and 351 days after earliest diagnosis are not shown. (B) Serum or plasma nucleocapsid in patients whose COVID-19 course was described as asymptomatic in clinical records. The $\mathrm{x}$ axis reflects time in between first known positive respiratory test and the day the blood sample used in our analysis was collected. (C) Serum or plasma nucleocapsid for individuals with positive nasopharyngeal RT-PCR on the same day as blood sample collection. 
medRxiv preprint doi: https://doi.org/10.1101/2022.01.23.22269354; this version posted January 27, 2022. The copyright holder for this preprint

(which was not certified by peer review) is the author/funder, who has granted medRxiv a license to display the preprint in perpetuity.

It is made available under a CC-BY-ND 4.0 International license.

Figure 4. Comparison of serum or plasma nucleocapsid levels in individuals with and without SARS-CoV-2-specific antibodies. Samples were tested by in-house developed serological tests for nucleocapsid and receptor binding domain specific IgG as well as receptor binding domain specific IgA and IgM. Levels of nucleocapsid are plotted and compared in samples stratified by seropositivity for each antibody type.

Figure 5. Comparison of serum or plasma nucleocapsid levels by (A-C) severity and (D-E) inflammatory biomarkers. Intubation in figures B and C includes intubation within 30 days before or after the blood sample was collected.

Individuals with severe COVID as defined by the composite of 30-day intubation or mortality are highlighted in D and E. 
medRxiv preprint doi: https://doi.org/10.1101/2022.01.23.22269354; this version posted January 27, 2022. The copyright holder for this preprint which was not certified by peer review) is the author/funder, who has granted medRxiv a license to display the preprint in perpetuity.

A. It is made available under a CC-BY-ND 4.0 International license . Blood sample (Day 0)

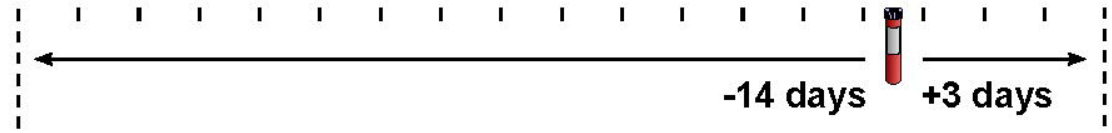

1. No known positive SARS-CoV-2 respiratory test. Only samples with same-day negative respiratory testing are labeled negative.

Same-day negative $\longrightarrow$

2. Any positive SARS-CoV-2 respiratory test. Earliest test determines assignment:

Convalescent

(Pre-window positive)

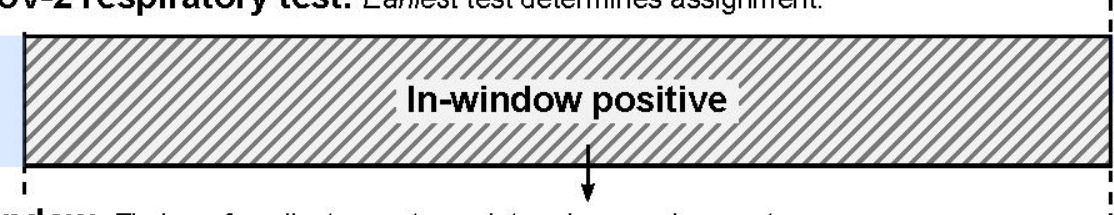

In-window positive
Post-window positive* $^{*}$

3. Earliest positive in window. Timing of earliest symptoms determines assignment:

Late-presenting

\section{Acute COVID}

Antigen level not measured (11) In complete or missing identifier (115) Same day, same patient (5) No SARS-CoV-2 respiratory test result (507) EXCLUDED

if a if a negative SARS-CoV-2 test is available following the sample but before the positive test. Otherwise, the sample is labeled "unknown."

B.

Any SARS-CoV-2 respiratory test result $(1,860)$

All samples $(2,498)$

Never SARS-CoV-2 positive $(1,416)$

Gold standard label: NEGATIVE

No same-day result $(1,222)$ EXCLUDED

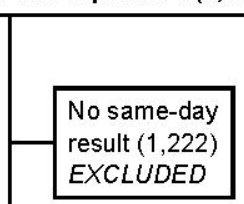

Same-day Negative (194)

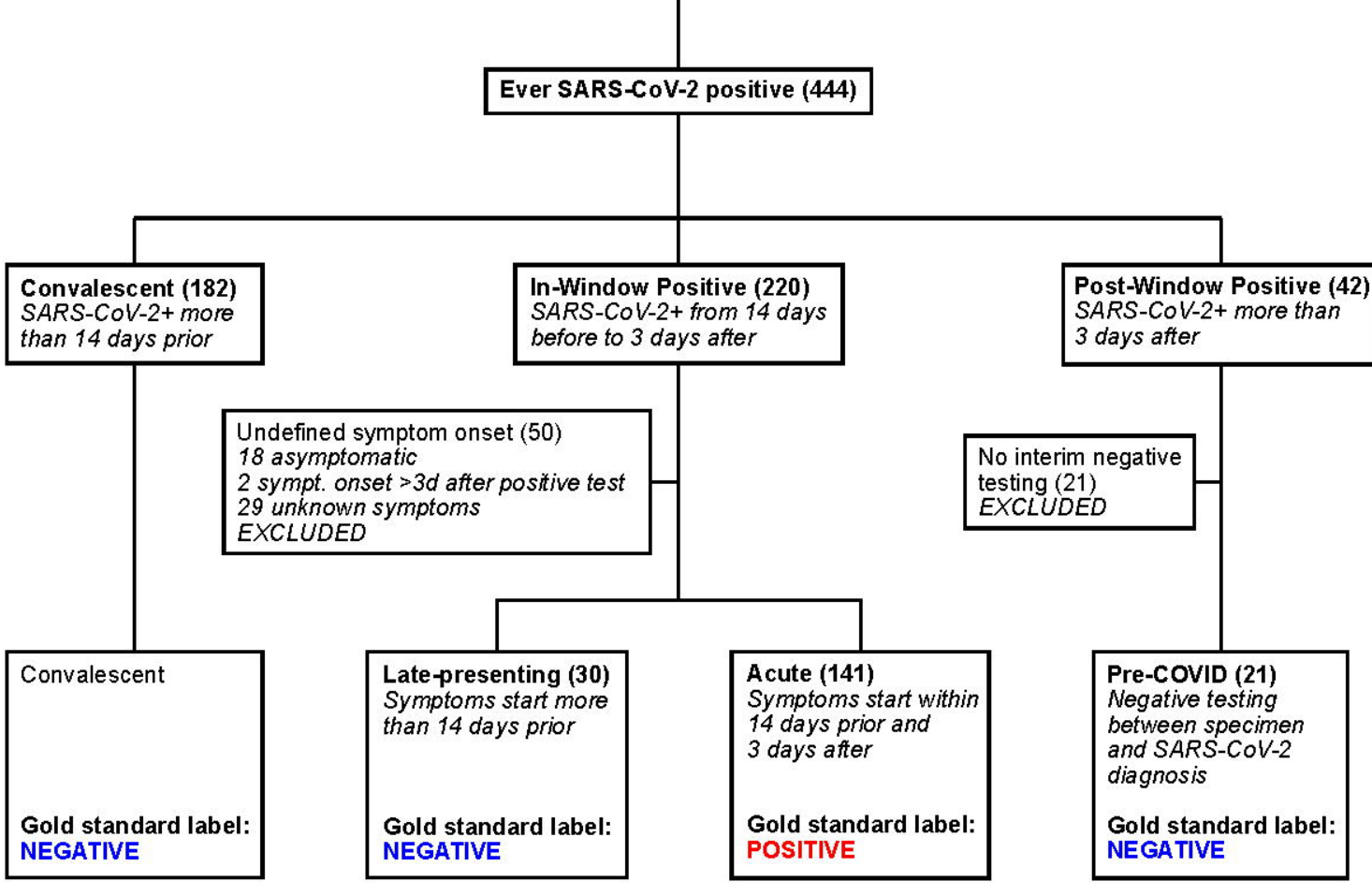



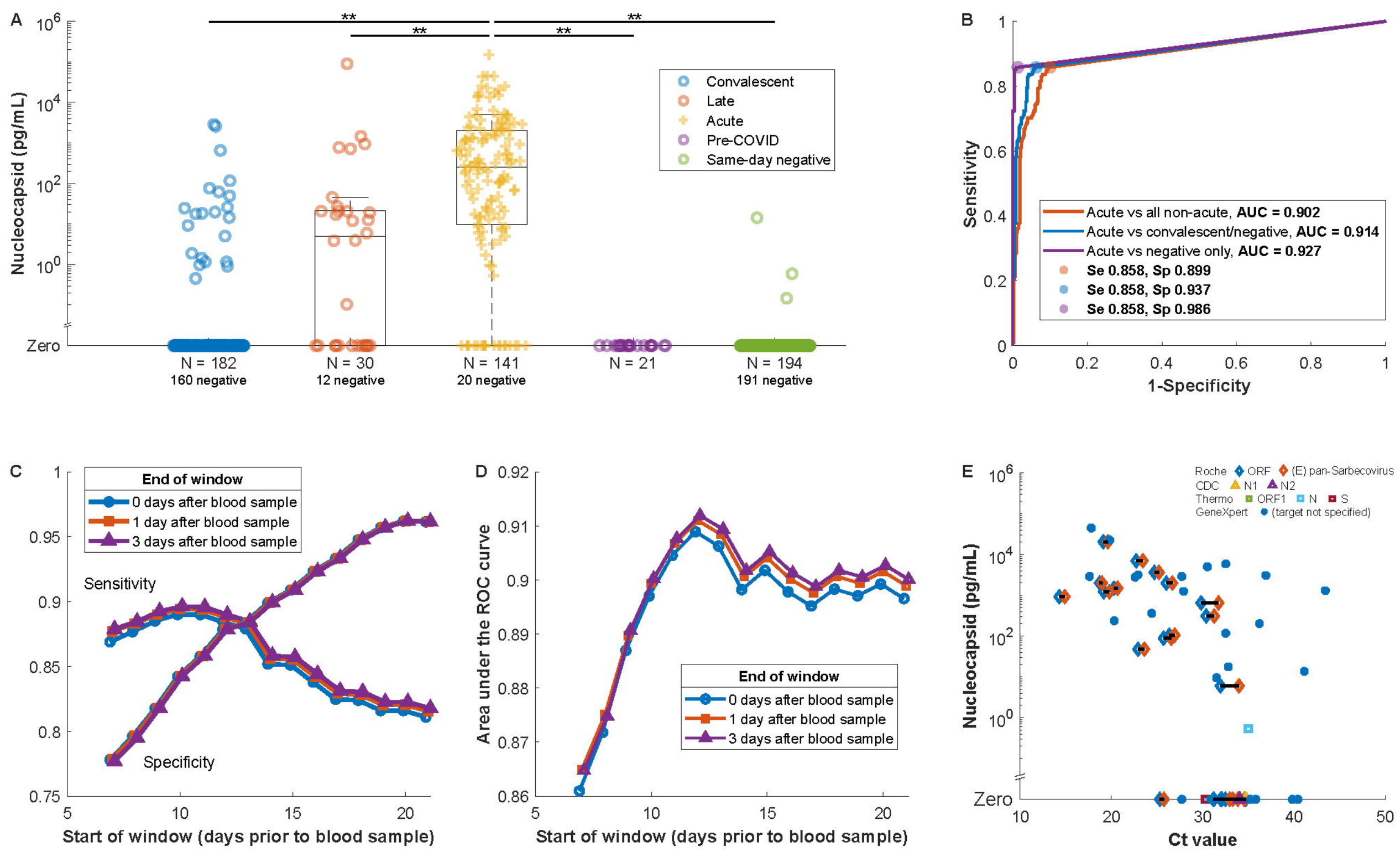
medRxiv preprint doi: https://doi.org/10.1101/2022.01.23.22269354; this version posted January 27, 2022. The copyright holder for this preprint (which was not certified by peer review) is the author/funder, who has granted medRxiv a license to display the preprint in perpetuity. It is made available under a CC-BY-ND 4.0 International license .
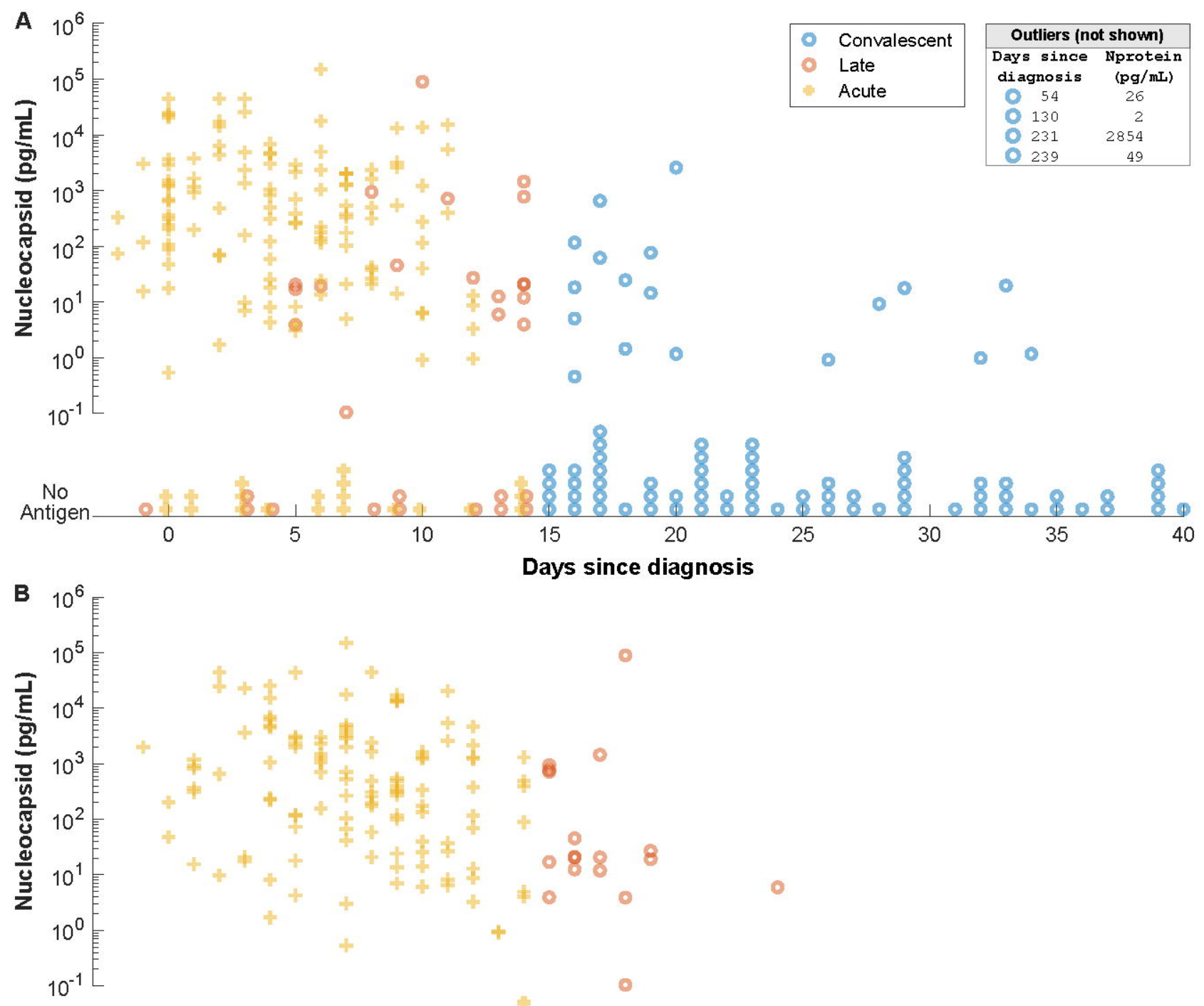

Days since diagnosis

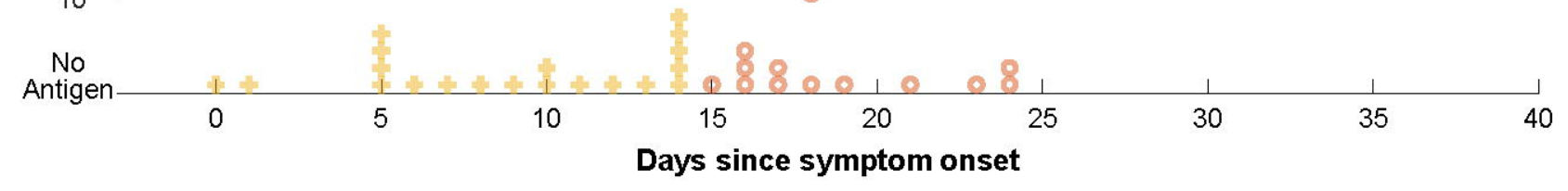

C

Asymptomatic patients

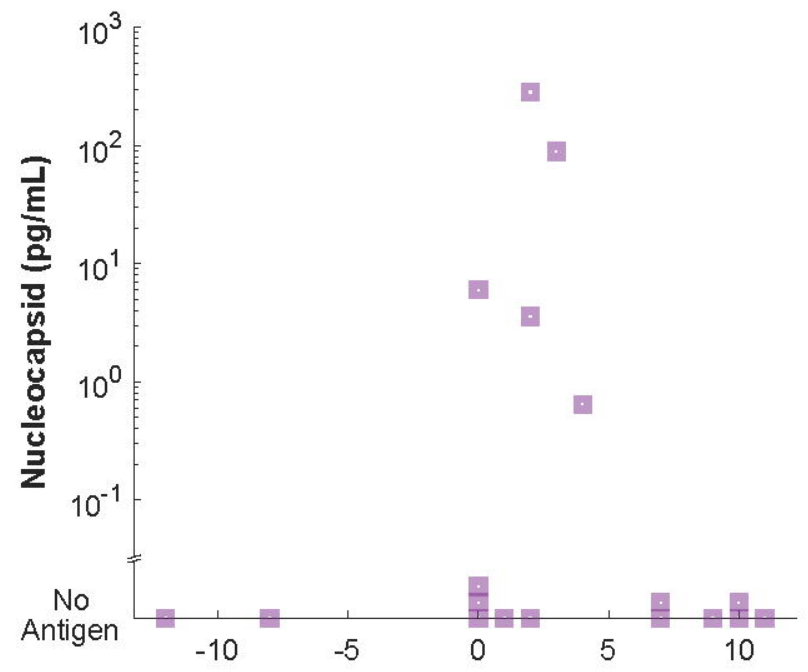

Days since earliest positive SARS-CoV-2 test
D Same-day positive nasopharyngeal RT-PCR

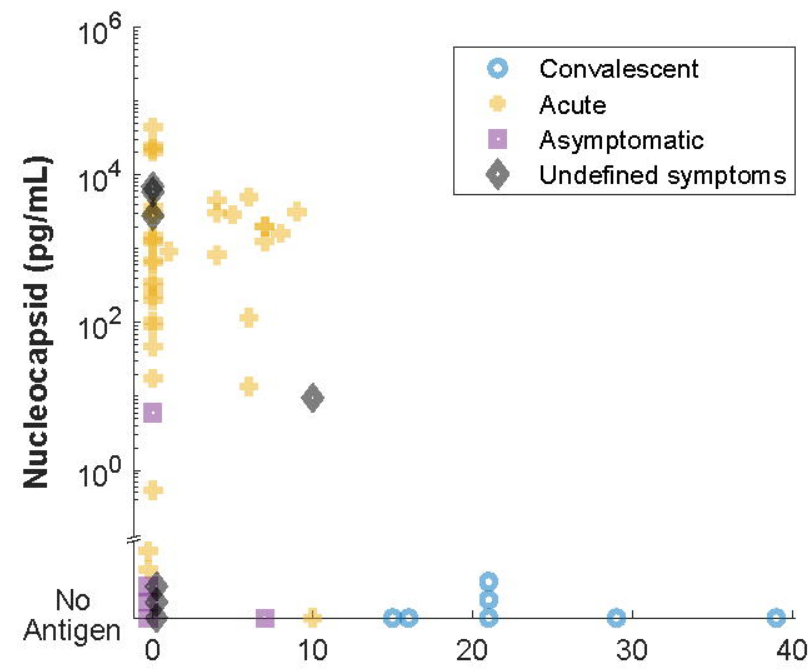

Days since earliest positive SARS-CoV-2 test 

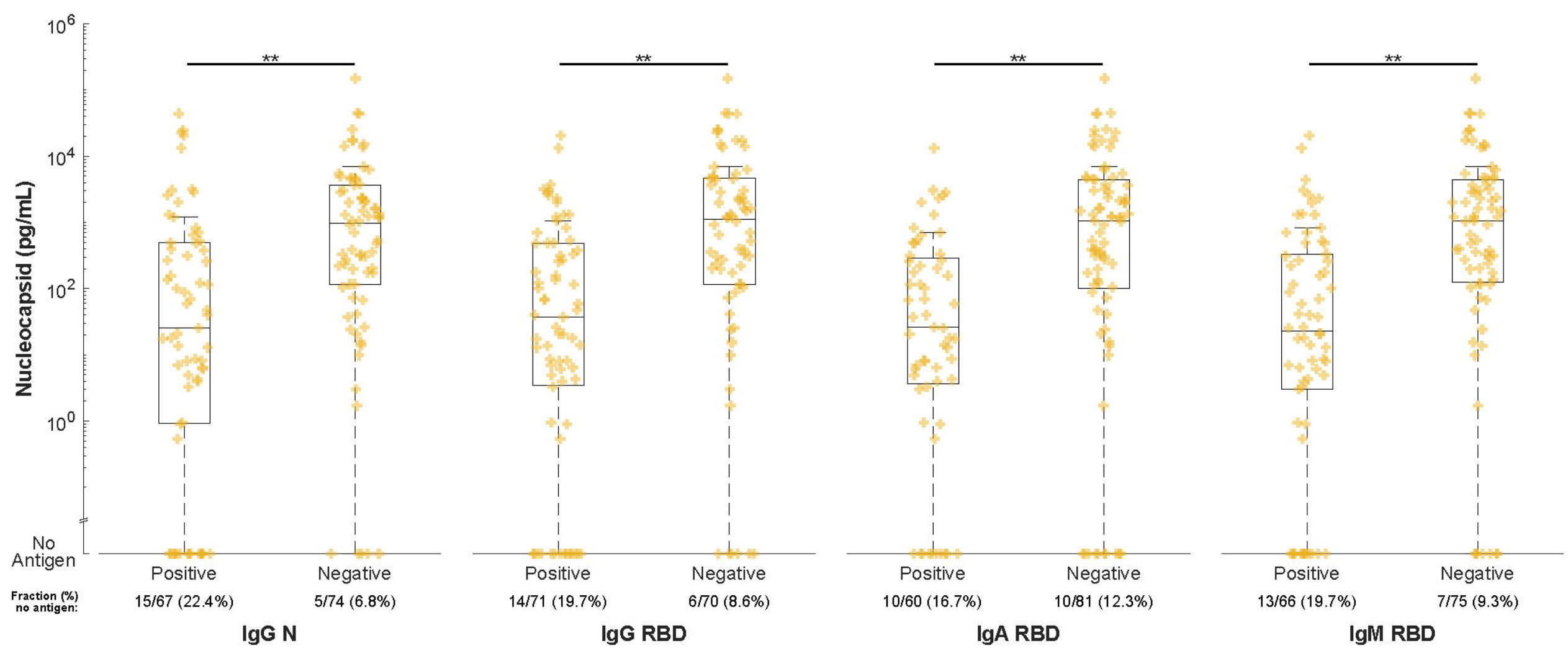

Figure 4 


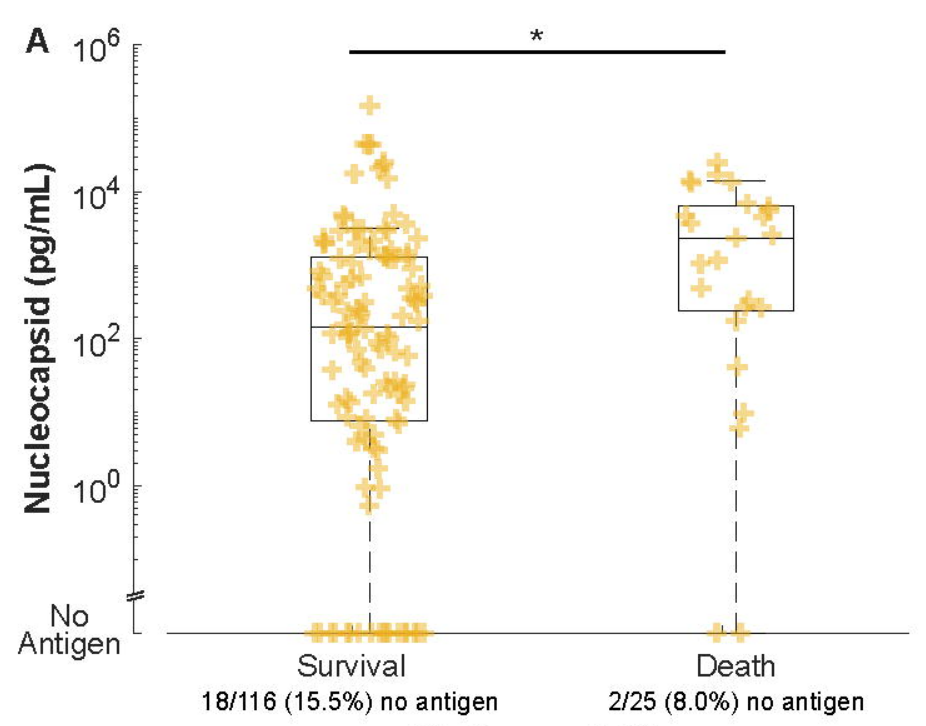

30-day mortality

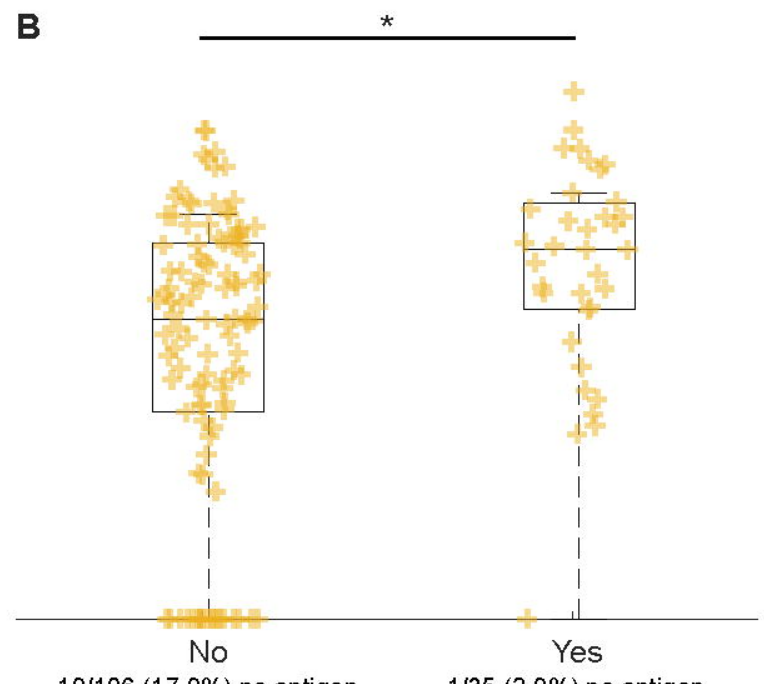

$19 / 106(17.9 \%)$ no antigen $\quad 1 / 35(2.9 \%)$ no antigen Intubation within $\mathbf{3 0}$ days
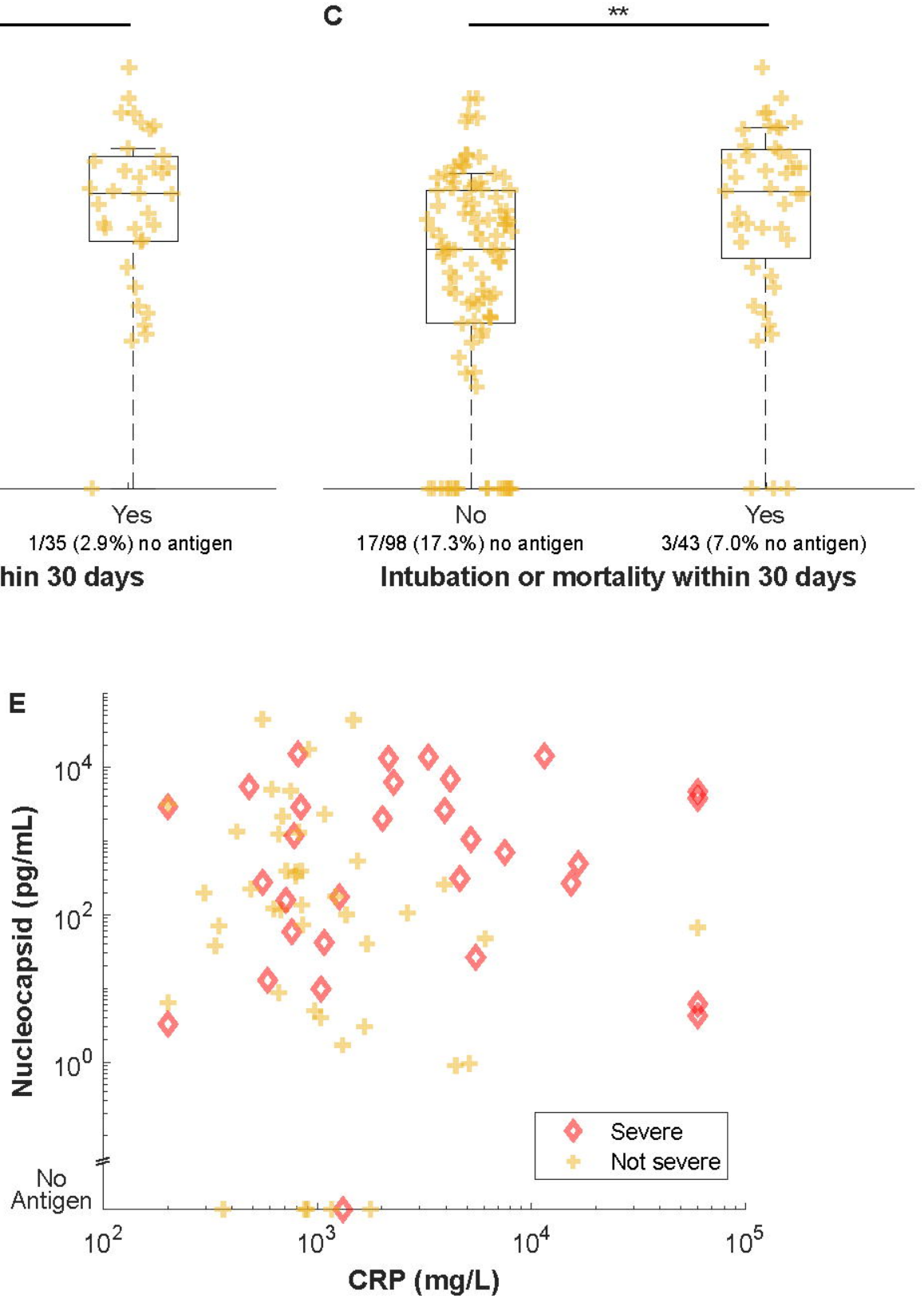

Figure 5 